\title{
粉 \\ A UTILIZAÇÃO DO REGIME DE URGÊNCIA NO PROCESSO DE CRIMINALIZAÇÃO: UMA ANÁLISE DOS PROJETOS DE LEI QUE INCLUÍRAM NOVOS TIPOS AO CÓDIGO PENAL ENTRE 2010 E 2019
}

\author{
THE USE OF FAST-TRACKING IN THE CRIMINALIZATION PROCESS: AN \\ ANALYSIS OF THE BILLS THAT INCLUDED NEW CRIMES IN THE BRAZILIAN \\ PENAL CODE BETWEEN 2010 AND 2019
}

\author{
LA UTILIZACIÓN DEL RÉGIMEN DE URGENCIA EN EL PROCESO DE \\ CRIMINALIZACIÓN: UNA ANALISE DE LOS PROYECTOS DE LEY QUE \\ INCLUIRÁN NUEVOS TIPOS PENALES AL CÓDIGO PENAL BRASILEÑO ENTRE \\ LOS AÑOS DE 2010 Y 2019
}

\author{
Glexandre de Souza Calixto ${ }^{1}$ \\ Iara Maria Machado Lopes ${ }^{2}$
}

\begin{abstract}
Resumo: Ao tratar do regime de urgência no processo legislativo brasileiro, o trabalho busca interpretá-lo, identificando os efeitos do procedimento para além da previsão regimental. Assim, se objetiva discutir a utilização deste regime na tramitação de Projetos de Lei que acrescentaram nova tipificação ao Código Penal entre 2010 e 2019. Se pretendeu levantar quantitativamente os Projetos que caminharam sob urgência; nos casos afirmativos, analisar se os requerimentos para tal foram justificados e o teor das fundamentações. Por fim, sugestionaram-se proposições de aprimoramento. Além da revisão bibliográfica, foram feitas consultas aos sites da Câmara e do Senado, bem como a análise documental dos projetos de leis. Pôde-se notar a ausência de robustas justificações para pedir e manter a urgência, demonstrando, dentre outras coisas, a transigente aplicação do instituto na prática parlamentar. É premente, assim, a necessidade do pensamento acadêmico se voltar a aperfeiçoar o procedimento, especialmente na área criminal.
\end{abstract}

Palavra-chave: Processo Legislativo; Regime de Urgência; Código Penal; Criminalização.

\begin{abstract}
Dealing with the fast-tracking in the Brazilian legislative process, the paper seeks to interpret it and identify the effects of the procedure beyond the regulatory provision. In this sense, the research aims to discuss the use of fast-tracking in the processing of bills that added a new crime to the Penal Code between 2010 and 2019. If it was intended to raise quantitatively the bills that went under fast-tracking procedure; in affirmative cases, analyze whether the requirements for this were justified and the ground basis. Finally, proposals for improvement were suggested. In addition to the bibliographic review, consultations were made to the House and Senate websites, as well as the documentary analysis of the bills. It was possible to notice the absence of robust justifications for requesting and maintaining fast-tracking, demonstrating, among other things, the not so rigorous application of the procedure in congress practice. Thus, there is an urgent need for academics to improve the procedure, especially in the criminal area.
\end{abstract}

\footnotetext{
${ }^{1}$ Graduando em Direito pela Universidade Federal de Santa Catarina. Pesquisador Voluntário de Iniciação Científica da UFSC. Membro do Grupo de Criminologia Vera Andrade e dos Grupos de Pesquisas Cautio Criminalis e Poder, Controle e Dano Social. E-mail: glexandre@ hotmail.com.

${ }^{2}$ Graduada em Direito pela Universidade Federal de Santa Catarina (UFSC). Residente (estagiária de pós-graduação) na Defensoria Pública de Santa Catarina. Coordenadora Adjunta do Instituto Brasileiro de Ciências Criminais (IBCCrim) em SC. Pós-graduanda lato sensu em Direito e Processo Penal pela Academia Brasileira de Direito Constitucional (ABDConst). Autora do livro "O sistema penal brasileiro em tempos de lavajatismo". Colunista semanal pela Emais Editora. Membro do corpo editorial da Revista Avant, do Grupo de Estudos e Pesquisas Cautio Criminalis e do Grupo de Estudos e Extensão Legisla UFSC. E-mail: mmlopesiara@ gmail.com
} 
Keywords: Legislative Process; Fast-tracking; Brazilian Penal Code; Criminalization.

Resumen: Al abordar el régimen de urgencia en el proceso legislativo brasileño, el trabajo busca interpretarlo, identificando los efectos del procedimiento más allá de la descripción del regimiento interno. Así, el objetivo es discutir la utilización de este régimen en la tramitación de Proyectos de Ley que agregaron nuevos crímenes al Código Penal brasileño entre 2010 y 2019. Si se pretendía seleccionar los Proyectos que pasaron en urgencia; en caso afirmativo, analizar si los requisitos para ello estaban justificados y el contenido de las razones. Además de la revisión bibliográfica, se realizaron consultas a los sitios web de la Cámara y el Senado, así como el análisis documental de los PLs. Se pudo notar la ausencia de justificaciones sólidas para solicitar y mantener la urgencia, demostrando, la aplicación comprometedora del instituto en la práctica parlamentaria. Por lo tanto, existe una necesidad urgente del pensamiento académico se centrará en perfeccionar el procedimiento, especialmente en el área penal.

Palabras clave: Proceso Legislativo; Régimen de Urgencia; Código Penal brasileño; Criminalización.

\section{Introdução}

O processo legislativo brasileiro a partir da complexidade que lhe é inerente conta com uma série de mecanismos de ordem formal e informal para o manuseio de seus ritos e suas dinâmicas. Dentre eles, encontra-se a previsão constitucional e regimental pela pluralidade de regimes de tramitação. As iniciativas normativas em tramitação no Congresso Nacional, assim, podem seguir sob o rito ordinário, especial ou, nos que o tornam mais célere, prioritário ou urgente. É quanto a última das espécies que concentra o trabalho.

A delimitação do tema da pesquisa buscou analisar este que é um dos institutos do processo legislativo federal: o regime de urgência, mais especificamente dentro de produções na seara criminal (relação ainda pouco explorada na literatura nacional). Dentro desse cenário, o problema central do trabalho pretende averiguar se a necessidade dos Projetos de Leis (PLs) que incluíram novos tipos ao Código Penal (CP) entre 2010 e 2019 tramitarem em regime de urgência foi justificada em algum momento do processo legislativo. Em caso de assertiva, identificar a tônica da fundamentação.

Parte-se do pressuposto de que a justificação pela imprescindibilidade da urgência é essencial à marcha legislativa e igualmente fundamental em iniciativas de disciplina penal. Isso, pois, evidencia como determinada matéria supostamente exige do Parlamento maior celeridade na apresentação de respostas aos problemas públicos. De igual forma, a fundamentação é crucial para justificar o abandono do processo de tramitação ordinário, que naturalmente comporta mais espaço e mais tempo à discussão do projeto.

A metodologia adotada opera sob o método indutivo. Para tal, como procedimento instrumental, o trabalho baseia-se na análise legislativa dos PLs promulgados entre 2010 e 2019 que tipificaram nova conduta no Código Penal. Além do mais, de maneira a ponderar a análise e suas conclusões, utilizou-se também de revisão bibliográfica.

Irá se fazer uma breve revisão do que prevê o ordenamento brasileiro - na Constituição e nos Regimentos Internos da Câmara e do Senado - quanto ao regime de urgência. Por conseguinte, através da análise legislativa dos PLs que incluíram novos tipos ao CP entre 2010 e 
2019, se levantará quantos tramitaram em urgência, quais são as outras informações que podem ser extraídas da investigação e como foram veiculadas as justificativas pela urgência da tramitação e da matéria. Ao final, serão sugeridas singelas proposições com o intuito de sofisticar o instituto.

Diante do exposto, mostra-se como relevante estudar o instituto sob essas inquirições. Retrospectivamente, é preciso investigar a maneira pela qual foi utilizado e, prospectivamente, identificar melhores e racionais maneiras dele ser manuseado dentro do processo legislativo criminal.

\section{0 regime de urgência no processo legiferante brasileiro: entre as previsões constitucionais e regimentais}

Conforme mencionado, as proposições legislativas no Congresso podem tramitar sob o rito ordinário, especial, prioritário ou urgente (simples e urgentíssima). Os ritos ditam a maneira e o tempo pelos quais serão encaminhadas as iniciativas. O regime de urgência, em exame, possui como precípua característica a celeridade que imputa ao processo legislativo, uma vez que dispensa prazos e formalidades regimentais inevitáveis aos outros ritos (com a exceção dos pareceres, quórum para deliberação e a distribuição de cópias das principais).

Podem ser identificadas duas espécies de regime de urgência, no geral diferenciadas pelo postulante: o constitucional, solicitado apenas pelo(a) Presidente da República em projetos de sua iniciativa; e o estritamente regimental, requerido pelos(as) parlamentares no curso da tramitação.

Na hipótese constitucional, a Câmara e o Senado deverão se manifestar sobre a proposição presidencial em até quarenta e cinco dias, sucessivamente. Sendo o prazo expirado sem posicionamento, a Constituição orienta que as demais deliberações legislativas das Casas sobrestarão até a votação, com exceção das que tenham prazo constitucional determinado ${ }^{3}$.

Quanto à urgência requerida pelos(as) congressistas, como dito, é no Regimento Interno (RI) de cada Casa que se encontra amparada, tanto no Regimento Interno do Senado Federal (RISF) $^{4}$ quanto no Regimento Interno da Câmara dos Deputados (RICD) ${ }^{5}$. Poderão propor urgência as comissões, uma percentagem da Mesa ou dos membros totais da Casa, a depender da matéria e do contexto.

\footnotetext{
3 Art. 64. [...] $\S 2^{\circ}$ Se, no caso do $\S 1^{\circ}$, a Câmara dos Deputados e o Senado Federal não se manifestarem sobre a proposição, cada qual sucessivamente, em até quarenta e cinco dias, sobrestar-se-ão todas as demais deliberações legislativas da respectiva Casa, com exceção das que tenham prazo constitucional determinado, até que se ultime a votação (BRASIL, 1988, n.p.).

${ }^{4}$ Art. 338. A urgência pode ser proposta: I - no caso do art. 336, I, pela Mesa, pela maioria dos membros do Senado ou líderes que representem esse número; II - no caso do art. 336, II, por dois terços da composição do Senado ou líderes que representem esse número; III - no caso do art. 336, III, por um quarto da composição do Senado ou líderes que representem esse número; IV - por comissão, nos casos do art. 336, II e III; V - pela Comissão de Assuntos Econômicos, quando se tratar de pedido de autorização para realizar operações de crédito previstas nos arts. 28 e 33 da Resolução $n^{\circ}$ 43, de 2001 (BRASIL, 1970, n.p.)

${ }^{5}$ Art. 154. O requerimento de urgência somente poderá ser submetido à deliberação do Plenário se for apresentado por: I - dois terços dos membros da Mesa, quando se tratar de matéria da competência desta; II - um terço dos membros da Câmara, ou Líderes que representem esse número; III - dois terços dos membros de Comissão competente para opinar sobre o mérito da proposição (BRASIL, 1989, n.p.).
} 
Um dos pontos cruciais para compreender o emprego do regime de urgência é revisar quais são as hipóteses que em tese justificam o seu requerimento. Pelo RISF (BRASIL, 1970, n.p.), é possível em matérias que envolvam perigo para a segurança nacional ou para atender calamidade pública; se pretenda apreciar na segunda sessão deliberativa ordinária subsequente; pendentes de parecer que se queira incluir na Ordem do Dia. Já no RICD (BRASIL, 1989, n.p.) para matérias que: envolvam a defesa da sociedade democrática e das liberdades fundamentais; para atender calamidade pública; visem prorrogar prazos legais ou alterar/adotar leis que se aplicarão em época certa e próxima; se pretenda apreciar na mesma sessão.

Relevante destacar a chamada urgência urgentíssima, prevista do art. 155 do RICD ${ }^{6}$. O instituto acelera ainda mais o processo legislativo na Câmara, afinal, ao ser requerido, poderá ser incluído automaticamente na Ordem do Dia para ser discutido e votado de forma imediata. Nos termos do Regimento, só poderá ser aprovada a urgência urgentíssima se a proposição versar sobre matéria de relevante e inadiável interesse nacional.

Apesar desses requisitos de fato constarem nos regimentos internos, devido ao caráter técnico de suas redações abertas, autorizam um uso pouco justificado da urgência pelos(as) parlamentares. Isso, porque, para que se possa solicitar o rito urgente (simples ou urgentíssima) o requerimento se baseia ou em hipóteses excessivamente abstratas - como o perigo à segurança nacional ou relevante e inadiável interesse nacional — ou em outras que morrem sendo apenas a vontade inexplicada do(a) congressista em transferir para data mais próxima a análise da proposição - como quando o requisito se fundamenta unicamente na pretensão de apreciá-la na mesma sessão.

Dessa forma, à exceção da previsão no RICD para projetos que visem prorrogar prazos legais ou alterar/adotar leis que se aplicarão em época certa e próxima, inexistem critérios racionais que tentem extrair com mais rigor a verdadeira intenção do(a) congressista em agilizar o trâmite legislativo.

Importa exemplificar alguns dos efeitos práticos da utilização do regime de urgência na tramitação. Para isso, cabe referenciar Simone Mendes (2002, p. 25-27, grifos nossos) que enumera alguns deles - ainda que seja um rol a partir do RICD muito se reproduz no RISF:

Pode ser dispensado, por exemplo, o segundo turno de apreciação dos projetos de lei complementar, cuja urgência tenha sido aprovada. Da mesma forma, não é necessária a antecedência de três dias para comunicar ao autor de proposição urgente que sua matéria está na Ordem do Dia das Comissões (art. 57, VIII). Algumas características da apreciação de matéria urgente: a) proposições urgentes não se submetem à apreciação conclusiva das Comissões. Significa que sempre vão ao Plenário da Câmara; b) o relator de matéria urgente não

\footnotetext{
${ }^{6}$ Art. 155. Poderá ser incluída automaticamente na Ordem do Dia para discussão e votação imediata, ainda que iniciada a sessão em que for apresentada, proposição que verse sobre matéria de relevante e inadiável interesse nacional, a requerimento da maioria absoluta da composição da Câmara, ou de Líderes que representem esse número, aprovado pela maioria absoluta dos Deputados, sem a restrição contida no $\S 2^{\circ}$ do artigo antecedente (BRASIL, 1989, n.p.).
} 
pode ter seu prazo prorrogado; c) não pode ser aceito pedido de vista de proposição urgente; d) não há interstício para proposições em regime de urgência; e) Conflito de competência de duas ou mais Comissões sobre matéria urgente deve ser resolvido imediatamente pelo Presidente da Câmara. Nos demais casos, o Presidente tem prazo de duas sessões; f) As proposições urgentes gozam de preferência para inclusão na Ordem do Dia; g) Em discussão e no encaminhamento da votação de matéria urgente, os oradores falam pela metade do prazo concedido nas matérias em regime ordinário ou em prioridade; h) As Comissões têm prazo conjunto de uma sessão para emitir parecer sobre as emendas à matéria urgente apresentadas em Plenário; i) a matéria será distribuída simultaneamente (o contrário da regra normal de tramitação sucessiva) para as Comissões envolvidas. Aqui ocorre a possibilidade de que, em função da análise concomitante mas não conjunta, uma determinada Comissão proponha certa modificação flagrantemente inconstitucional à matéria, alterando o texto original, de forma que somente o Plenário da Casa poderá sanar tal incorreção quando os diferentes pareceres das diferentes Comissões forem a ele remetidos, e se algum parlamentar vier a levantar questão de ordem sobre o fato; j) As proposições urgentes só podem receber emendas de Comissão, ou emendas apresentadas por 1/5 dos membros da Câmara ou Líderes que representem esse número. Diferente das proposições em regime de urgência, os projetos de iniciativa do Presidente da República para os quais haja sido solicitada urgência, o $§ 12$, inc. 111 do Ato da Mesa ${ }^{\circ}$ 177/89 estabelece que antes do envio da matéria às comissões, o Presidente da Câmara abrirá prazo de cinco sessões para apresentação de emendas em plenário. Decorrido esse prazo, o projeto e as emendas serão distribuídos às comissões competentes para opinar sobre a matéria; k) Se o projeto não tiver sido apreciado definitivamente pelo Plenário da Casa em até 45 dias após o pedido de urgência, será ele incluído na ordem do dia, sobrestando-se a deliberação quanto aos demais assuntos, para que se ultime a votação; l) Decidido o assunto versado no projeto, no âmbito da Câmara, deve ele ser enviado ao Senado Federal, que deverá apreciá-lo em 45 dias. Há a hipótese de o Senado apresentar emendas à proposição, que nesse caso deverá retomar à Câmara no prazo de 10 dias, findo o qual será sobrestada a deliberação quanto aos demais assuntos, a fim de que ultime a sua votação.

Mesmo não esgotando todas as hipóteses regimentais, o quadro trazido é de extrema importância, haja vista evidenciar como a adoção do regime de urgência provoca uma série de mudanças que reduzem interstícios, agilizam procedimentos e, em última análise, comprimem o espaço de deliberação e exame da matéria. Em função disso, especificamente por potencializar a redução da arena de discussão das proposições, é que se mostra crucial fortalecer as justificações para optar pelo regime urgente, e não pelo ordinário.

\section{O uso do regime urgente dentre os PLs que incluíram novos tipos ao Código Penal de 2010} a 2019

Neste item será analisado propriamente o emprego do regime de urgência dentro dos PLs promulgados entre 2010 e 2019 que tipificaram nova conduta no Código Penal, seja pela inclusão formal de novo tipo com preceitos primários e secundários próprios ${ }^{7}$, seja pela criação de

\footnotetext{
${ }^{7}$ Cabe pontuar a opção em incluir o Projeto de Lei no 643/2011 (número dado ao PL na Câmara) que, apesar de não criar do zero os delitos de descaminho e contrabando, os separa em dois artigos distintos e modifica em significância suas redações. Por esses motivos foi objeto de análise. Há ainda o caso da Lei n ${ }^{\circ}$ 13.968/2019 que incluiu novas condutas elementares e substanciais ao crime do art. 122 do CP.
} 
qualificadora ou causa de aumento com titulação própria, como no caso do feminicídio e do estelionato contra idoso.

Portanto, serão compartilhados as diretrizes e a metodologia da pesquisa, alguns dos seus resultados preliminares, bem como uma análise de como são manuseados os fundamentos de urgência - tanto dela como regime de tramitação como ferramenta discursiva para a premência e importância da matéria para a sociedade.

\subsection{Diretrizes e metodologia}

A análise dos processos legislativos se deu sob a seara de construção formal da política (RABELO; QUEIROZ, 2019), afinal se objetivou com as análises averiguar como os(as) legisladores(as) utilizaram o mecanismo da tramitação em urgência na área criminal, estabelecendo como recorte a análise dos projetos de lei que posteriormente criaram novas tipificações no Código Penal, no período de 2010 a 2019.

A opção em filtrar os PLs dentre aqueles específicos de inclusão de novas espécies de tipificação no CP deriva-se: primeiro, da modéstia em escolher apenas uma postura normativa de um único diploma legal; segundo, porque se mostra interessante observar os Projetos de Lei que chegaram a ser promulgados de fato, pela potencialidade de produzirem efeitos reais na vida social, além da possibilidade de analisar como o projeto tramitou em ambas as casas legislativa; terceiro, da percepção a priori de que é nítido compreender os discursos de urgência e emergência nos movimentos que buscam criminalizar novas condutas.

A escolha por delimitar a análise a esse período temporal, qual seja o de 2010 a 2019, se baseou em pelo menos três razões: em primeiro lugar, por dever de honestidade com o objeto de pesquisa, não mostrou ser viável expandir ainda mais o intervalo e, assim, comprometer a análise; em segundo, pela proximidade temporal com o período de realização da pesquisa; por fim, por ser o momento de maior disseminação do uso da internet para, dentre outros, como espaço de reivindicação por pautas criminalizadoras.

Para realizar o filtro de pesquisa, foi utilizado como referência a data de promulgação das leis que criaram tipificações, nos padrões acima referenciados, disponíveis no Código Penal virtual consolidado no site do Planalto (BRASIL, 1940), dentro da delimitação temporal proposta. Por consequência, foi nos sites da Câmara dos Deputados e do Senado Federal que foi possível acompanhar com detalhamento a tramitação dos PLs selecionados.

Como metodologia de análise, se catalogou os Projetos de Lei e a eles (e a seus trâmites) se fez as seguintes perguntas: (1) Qual a ementa e o conteúdo da norma?; (2) Criminaliza uma nova conduta? Qual?; (3) Qual foi a Casa Iniciadora, e consequentemente, qual a Revisora?; (4) De quem é a autoria do PL?; (5) O Projeto de Lei tramitou em regime de urgência? Se não, em qual?; (6) Qual foi a justificativa apresentada para a proposição legislativa? Nela existe alguma referência a necessidade de urgência da matéria ou a casos de grande repercussão?; (7) O(A) 
Parlamentar proponente citou em algum momento da tramitação algum caso midiático da sociedade civil acerca do conteúdo do Projeto?; (8) Existiu alguma fundamentação para o requerimento, e para sua consequente votação, da tramitação em urgência?; (9) Nos debates nas Comissões Parlamentares e em Plenário há menção ou defesa da urgência da matéria? Se sim, como se procedeu?; (10) Qual foi o tempo médio de tramitação?

\subsection{Resultados preliminares}

Inicialmente, anuncia-se que de 2010 a 2019, 13 (treze) foram os PLs, promulgados ao final, que incluíram novos tipos ao Código Penal, resultando nas seguintes leis (Tabela 1):

Tabela 1 - PLs que incluíram novos tipos ao Código Penal entre 2010 e 2019

\begin{tabular}{|c|c|c|c|}
\hline $\begin{array}{c}\text { Número da } \\
\text { Lei }\end{array}$ & $\begin{array}{c}\text { Ano de } \\
\text { promulgação }\end{array}$ & Autoria & Ementa \\
\hline 12.550 & 2011 & $\begin{array}{l}\text { Poder Executivo ( } 1^{\circ} \\
\text { Governo Dilma) }\end{array}$ & $\begin{array}{c}\text { Autoriza o Poder Executivo a criar a } \\
\text { empresa pública denominada Empresa } \\
\text { Brasileira de Serviços Hospitalares - } \\
\text { EBSERH; acrescenta dispositivos ao } \\
\text { Decreto-Lei n }{ }^{\circ} 2.848 \text {, de } 7 \text { de dezembro } \\
\text { de } 1940 \text { - Código Penal; e dá outras } \\
\text { providências. }\end{array}$ \\
\hline 12.653 & 2012 & $\begin{array}{l}\text { Poder Executivo ( } 1^{\circ} \\
\text { Governo Dilma) }\end{array}$ & $\begin{array}{l}\text { Acresce o art. 135-A ao Decreto-Lei n } \\
\text { 2.848, de } 7 \text { de dezembro de } 1940 \text { - } \\
\text { Código Penal, para tipificar o crime de } \\
\text { condicionar atendimento médico- } \\
\text { hospitalar emergencial a qualquer garantia } \\
\text { e dá outras providências. }\end{array}$ \\
\hline 12.720 & 2012 & $\begin{array}{c}\text { Deputado Luiz Couto - } \\
\text { PT/PB }\end{array}$ & $\begin{array}{l}\text { Dispõe sobre o crime de extermínio de } \\
\text { seres humanos; altera o Decreto-Lei n } \\
2.848 \text {, de } 7 \text { de dezembro de } 1940 \text { - } \\
\text { Código Penal; e dá outras providências. }\end{array}$ \\
\hline 12.737 & 2012 & $\begin{array}{c}\text { Deputados(as): } \\
\text { Paulo Teixeira - PT/SP } \\
\text { Luiza Erundina - } \\
\text { PSB/SP } \\
\text { Manuela D'ávila - } \\
\text { PCdoB/RS } \\
\text { João Arruda - } \\
\text { PMDB/PR } \\
\text { Brizola Neto - PDT/RJ } \\
\text { Emiliano José - PT/BA }\end{array}$ & $\begin{array}{l}\text { Dispõe sobre a tipificação criminal de } \\
\text { delitos informáticos; altera o Decreto-Lei } \\
\text { no }^{\circ} 2.848 \text {, de } 7 \text { de dezembro de } 1940 \text { - } \\
\text { Código Penal; e dá outras providências }\end{array}$ \\
\hline 13.008 & 2014 & $\begin{array}{c}\text { Deputado Efraim Filho } \\
\text { - DEM/PB }\end{array}$ & $\begin{array}{l}\text { Dá nova redação ao art. } 334 \text { do Decreto- } \\
\text { Lei no } 2.848 \text {, de } 7 \text { de dezembro de } 1940 \text { - } \\
\text { Código Penal e acrescenta-lhe o art. } 334- \\
\text { A. }\end{array}$ \\
\hline 13.104 & 2015 & CPMI - Violência & Altera o art. 121 do Decreto-Lei $\mathrm{n}^{\circ} 2.848$ \\
\hline
\end{tabular}


Contra a Mulher - 2012$$
13.228
$$

13.344

13.445

13.718

13.772
2016

Deputado Afonso

Hamm - PP/RS

2016

2018

Deputado Márcio Marinho - PRB/BA

CPI/Senado Federal Tráfico Nacional e Internacional de

Pessoas no Brasil 2011

Senador Aloysio

Nunes Ferreira

(PSDB/SP)

Senadora Vanessa

Granzziotin

(PCdoB/AM)
Deputado João Arruda - PMDB/PR de 7 de dezembro de 1940 - Código Penal, para prever o feminicídio como circunstância qualificadora do crime de homicídio, e o art. $1^{\circ}$ da Lei $\mathrm{n}^{\circ} 8.072$, de

25 de julho de 1990, para incluir o feminicídio no rol dos crimes hediondos.

Altera o Decreto-Lei n ${ }^{\circ} 2.848$, de 7 de dezembro de 1940 - Código Penal, para estabelecer causa de aumento de pena para o caso de estelionato cometido contra idoso.

Altera o Decreto-Lei no 2.848 , de 7 de dezembro de 1940 (Código Penal), para tipificar, de forma mais gravosa, os crimes de furto e de receptação de semovente domesticável de produção, ainda que abatido ou dividido em partes.

Dispõe sobre prevenção e repressão ao tráfico interno e internacional de pessoas e sobre medidas de atenção às vítimas; altera a Lei $\mathrm{n}^{\circ} 6.815$, de 19 de agosto de 1980, o Decreto-Lei no 3.689, de 3 de outubro de 1941 (Código de Processo Penal), e o Decreto-Lei n 2.848 , de 7 de dezembro de 1940 (Código Penal); e revoga dispositivos do Decreto-Lei ${ }^{\circ}$ 2.848, de 7 de dezembro de 1940 (Código Penal).

Institui a Lei de Migração.

Altera o Decreto-Lei no 2.848 , de 7 de dezembro de 1940 (Código Penal), para tipificar os crimes de importunação sexual e de divulgação de cena de estupro, tornar pública incondicionada a natureza da ação penal dos crimes contra a liberdade sexual e dos crimes sexuais contra vulnerável, estabelecer causas de aumento de pena para esses crimes e definir como causas de aumento de pena o estupro coletivo e o estupro corretivo; e revoga dispositivo do Decreto-Lei $\mathrm{n}^{\circ} 3.688$, de 3 de outubro de 1941 (Lei das Contravenções Penais).

Altera a Lei $\mathrm{n}^{\circ} 11.340$, de 7 de agosto de 2006 (Lei Maria da Penha), e o DecretoLei $n^{\circ} 2.848$, de 7 de dezembro de 1940

(Código Penal), para reconhecer que a violação da intimidade da mulher configura violência doméstica e familiar e para criminalizar o registro não autorizado de conteúdo com cena de nudez ou ato sexual ou libidinoso de caráter íntimo e privado. 
A utilização do regime de urgência no processo de criminalização: uma análise dos Projetos de Lei que incluíram novos tipos ao Código Penal entre 2010 e 2019

Senador Ciro Nogueira $(\mathrm{PP} / \mathrm{PI})$
Altera o Decreto-Lei n ${ }^{\circ} 2.848$, de 7 de dezembro de 1940 (Código Penal), para modificar o crime de incitação ao suicídio e incluir as condutas de induzir ou instigar a automutilação, bem como a de prestar auxílio a quem a pratique.

Fonte: Elaboração própria com base na pesquisa legislativa nos portais das duas casas do Congresso, 2020.

A partir da tramitação de cada uma delas, algumas constatações foram possíveis de serem feitas.

\subsubsection{Sobre a matéria e a tipificação dos PLs em análise}

Num panorama geral, os Projetos de Lei que incluíram novos tipos ao Código Penal entre 2010 e 2019 se amotinaram em quatro prescrições distintas: acrescentaram do zero um novo tipo penal com preceitos primários e secundários próprios; criaram uma qualificadora ou causa de aumento com nova titulação; segregaram um tipo antigo em dois distintos, ou; acrescentaram novas condutas elementares a um tipo anterior.

A Lei de no 12.550/2011 enquanto tramitou na Câmara esteve sob a numeração 1749/2011 e no Senado foi identificada como Projeto de Lei da Câmara (PLC) nº 79/2011. A proposição, de origem do Poder Executivo, não nasceu a princípio como uma norma de caráter criminal, afinal o seu conteúdo girou em torno da ementa de autorizar o Executivo a criar a empresa pública Empresa Brasileira de Serviços Hospitalares S.A. (EBSERH). Contudo, dentre os seus tantos dispositivos de teor eminentemente administrativo, acabou tipificando o crime de fraudes em certames de interesse público como um daqueles praticados contra a fé pública.

A Lei no 12.653/2012, sob identificação no 3331/2012 na Câmara e PLC nº 34/2012 no Senado, também foi gestada por iniciativa do Poder Executivo e tipificou o crime de condicionamento de atendimento médico-hospitalar emergencial a qualquer garantia como um que dá causa a periclitação da vida e da saúde de alguém. Detalhamentos sobre a sua tramitação serão mencionados em item posterior.

Ao que se refere à Lei no 12.720/2012 — n 370/2007 na Câmara e PLC nº 137/2008 no Senado - ela criminalizou a constituição de milícia privada. A Lei teve o intuito também de repreender os grupos de extermínio, motivo pelo qual tornou essa condição de pertencimento uma majorante dos crimes de homicídio e lesão corporal. Nesse contexto, a legislação foi resultado prático dos trabalhos da CPI do Extermínio no Nordeste na Câmara e foi também impactada pelo contexto internacional, se fundamentando na obrigatoriedade dada pela Resolução no 44/162 da Assembleia Geral das Nações Unidas para que os países legislassem contra as execuções primárias. Na justificativa do projeto e em seus debates foi comum perceber a menção a eventos como os massacres de Carandiru, da Candelária e de Eldorado dos Carajás e a contextualização do fenômeno das milícias especialmente nos cenários fluminense e nordestino de forma genérica. 
Identificada sob o n ${ }^{\circ}$ 2793/2011 dentro da Câmara dos Deputados e PLC nº 35/2012 no Senado Federal, a Lei n 12.737/2012 alterou o Código Penal para, dentre outras modificações, tipificar os crimes de falsificação de cartão e invasão de dispositivo informático. Conforme a própria ementa adverte, a tônica da legislação é a de regular mais afinco a previsão criminal dos chamados delitos informáticos, num contexto mais explícito de emergência da dita sociedade da informação.

A Lei no 13.008/2014 - no 643/2011 na Câmara e PLC nº 62/2012 no Senado - deu nova redação ao art. 334 do Código Penal, o desmembrando em dois ao acrescentar o art. 334-A ao diploma legal. Portanto, por rigor técnico, os crimes de descaminho e contrabando tornaramse autônomos, realidade não vislumbrada antes da Lei onde eles em muito se confundiam. As penas foram aumentadas.

Quanto à mudança introduzida pela Lei no $13.104 / 2015$ — n n $^{\circ}$ 292/2013 no Senado e $n^{\circ}$ 8.305/2014 na Câmara - merece menção que se trata de uma das mais repercutidas inovações no universo normativo da última década. Isso porque foi ela que tornou a figura do feminicídio uma circunstância qualificadora do crime de homicídio (ainda incluiu o feminicídio no rol dos crimes hediondos). De origem dos trabalhos da Comissão Parlamentar Mista de Inquérito (CPMI) de Violência Contra a Mulher, a mudança não introduziu do zero uma nova conduta penal, afinal permanece ainda como condição nuclear a existência do homicídio em si. Contudo, ela o qualifica por ser um tipo derivado autônomo, assim, especifica a conduta por ser contra a mulher pela condição do gênero feminino, introduz nova nomenclatura e torna a subsunção mais gravosa.

Na mesma toada do que ocorreu com o feminicídio, a Lei $n^{\circ} 13.228 / 2015$, que tramitou sob o $n^{\circ}$ 6920/2010 na Câmara e PLC nº 23/2015 no Senado, não originou uma novíssima conduta criminosa; apenas criou e deu titulação própria ao estelionato cometido contra idoso como sendo uma causa de aumento de pena do crime de estelionato.

Com a identificação de nº 6999/2013 na Câmara e PLC n 128/2015 no Senado, a Lei no 13.330/2016 adicionou ao Código o art. 180-A para criminalizar a conduta de receptação de animal. Para compreensão melhor do tipo, oportuna a transcrição do seu preceito primário:

\footnotetext{
Adquirir, receber, transportar, conduzir, ocultar, ter em depósito ou vender, com a finalidade de produção ou de comercialização, semovente domesticável de produção, ainda que abatido ou dividido em partes, que deve saber ser produto de crime (BRASIL, 1940, n.p.).
}

A Lei $n^{\circ} 13.344 / 2016$ - no 479/2012 no Senado e no 7370/2014 na Câmara - é consequência das atividades da CPI de Tráfico Nacional e Internacional de Pessoas no Brasil iniciada em 2011. A legislação dispôs sobre prevenção e repressão ao tráfico de pessoas e sobre medidas de atenção às vítimas, portanto, a orientação punitiva não é a sua principal característica. Contudo, dentre aquilo que prevê como mecanismo de repressão, tipificou o delito de tráfico de pessoas. 
A Lei $n^{\circ} 13.445 / 2017$ - no 288/2013 no Senado e no 2.516/2015 na Câmara — é a chamada Lei de Imigração. Fruto de diversos debates na sociedade, ela mudou consideravelmente a disposição das pessoas em imigração no Brasil, sendo vista por muitos como um avanço notável. Assim como a anterior, ela não figura como uma norma de caráter penal, porém acabou definindo uma nova conduta criminosa em seu texto. Diante disso, incluiu no Código Penal o crime de promoção de migração ilegal.

É pela Lei $n^{\circ} 13.718 / 2018$ - no 618/2015 no Senado e n 5.452/2016 na Câmara — que foram introduzidos no Código os delitos de importunação sexual e divulgação de cena de estupro ou de cena de estupro de vulnerável, de cena de sexo ou de pornografia. Também se tornaram causas de aumento com titulação própria o estupro coletivo e o estupro corretivo. Inicialmente o PL previa apenas a hipótese do estupro coletivo, muito em função de eventos noticiados no Brasil à época; depois, no decorrer do trâmite, outras figuras e outros PLs foram sendo incorporados até que se chegasse ao texto promulgado, representando ao final uma série de mudanças atinentes aos crimes sexuais. Dentro ainda da matéria, a Lei $n^{\circ} 13.772 / 2018$ - $\mathrm{n}^{\circ}$ 5555/2013 quando na Câmara e PLC n ${ }^{\circ}$ 18/2017 quando no Senado — criou no Código o Capítulo I-A no Título referente aos Crimes Contra A Dignidade Sexual e tipificou o crime de exposição pública da intimidade sexual.

Por fim, a Lei no 13.968/2019 — no 664/2015 no Senado e nº 8.833/2017 na Câmara —, modificou substancialmente o art. 122 do CP, a fim de que o crime de induzimento, instigação ou auxílio a suicídio ou a automutilação contemplasse especificamente as condutas de induzir ou instigar a automutilação. Para isso, o contexto dos parlamentares entusiastas do Projeto ao momento era o de referenciar o aumento de casos de indivíduos que buscariam influenciar crianças e adolescentes a se automutilarem.

\subsubsection{Sobre as tramitações}

Num primeiro momento, pela pesquisa, tornou-se perceptível a recorrência do uso de mecanismos aceleradores na tramitação dos PLs em exame. O gráfico abaixo (Figura 1) sintetiza as informações coletadas a respeito do regime de tramitação dos treze Projetos de Lei selecionados, conforme se vê: 
Figura 1 - Regimes de tramitação dos PLs analisados quando na Câmara e no Senado

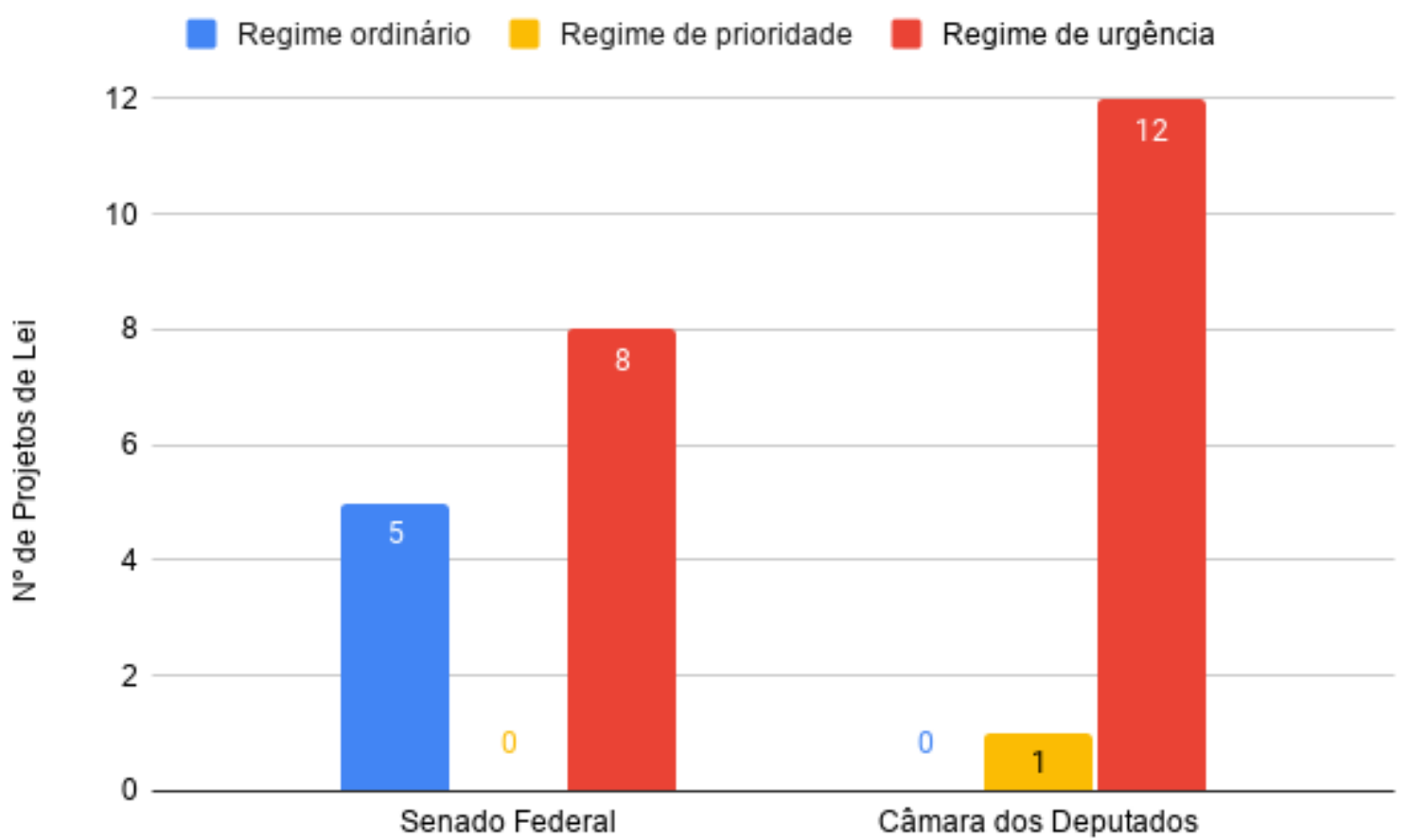

Fonte: Elaboração própria com base na pesquisa legislativa nos portais das duas casas do Congresso, 2020 .

Leia-se, portanto, que quando na Câmara, chama a atenção que dos treze PLs, 12 (doze) tramitaram em regime de urgência (urgentíssima) e 1 (um) em prioridade. Já no Senado, 8 (oito) em urgência e 5 (cinco) no regime ordinário. Logo, nenhum dos Projetos de Lei correu sob o regime ordinário na Câmara, e no Senado apenas aproximadamente $38 \%$ deles. O painel denota um interesse, ao menos inicial, de agilização do trâmite pelos(as) parlamentares.

Ressalta-se que na Câmara todos os PLs correram sob urgência urgentíssima. Como se constou no item 1, trata-se da espécie que mais apressura a tramitação e é a que tem apenas hipóteses abertas e subjetivas para poder ser requerida. Mesmo diante desse descompasso, foi o único mecanismo de aceleração utilizado na Câmara.

Curioso mencionar brevemente o caso da tramitação do PL que resultou na Lei 13.772/2018 e que tipificou o registro não autorizado da intimidade sexual. Nele, o pedido de urgência dentro da Câmara só foi feito depois dele agregar a criminalização em sua redação. Antes, quando era apenas uma mudança sem caráter punitivo na Lei Maria da Penha e estava nos moldes do texto original, tramitava em regime ordinário.

Em que pese a urgência ter sido amplamente utilizada nos PLs em análise, nota-se que inexiste um padrão temporal de promulgação deles, sendo que os projetos em média levaram 3 (três) anos, 1 (um) mês e 29 (vinte e nove) dias para serem aprovados. Dentre eles, a promulgação mais veloz ocorreu em 2 (dois) meses e 23 (vinte e três) dias e a mais morosa em 5 (cinco) anos, 
9 (nove) meses e 16 (dezesseis) dias, o que faz com que a diferença temporal entre os dois chegue a 5 (cinco) anos, 7 (sete) meses e 7 (sete) dias. Destarte, o cenário aponta para uma parca padronização dos efeitos do rito urgente, ainda que ele teoricamente dispense os mesmos procedimentos regimentais para todos os Projetos.

Dentro os PLs que caminharam em urgência, apenas em 1 (um) ${ }^{8}$ foi aquela denominada constitucional, ou seja, a requerida pelo(a) Presidente da República, mesmo que tenham sido 2 (dois) os Projetos de autoria do Executivo no período analisado9 ${ }^{9}$ Assim, todas as outras vezes que o rito urgente foi utilizado, foi requisitado com base exclusiva nos RIs, confirmando uma tendência já anunciada por Acir Almeida de diminuição da ingerência do Poder Executivo na aceleração da agenda legislativa.

Acir Almeida mostra que considerando os períodos de 1995-2002 e 2007-2014, a média anual de PLs do Executivo aprovados com urgência diminuiu de 28,7\% para 13,8\%, e a de aprovados conclusivamente nas comissões triplicou de $9,8 \%$ para $29,1 \%$. Segundo ele, as informações levam a conclusão de que com uma agenda legislativa mais descentralizada:

[...] o timing de quantidade crescente de decisões legislativas passou a ser definido pelas várias comissões permanentes, e não mais pelo Executivo (via uso de MPV e urgência constitucional) e pelas lideranças partidárias (via urgência regimental e o controle da pauta do plenário) (ALMEIDA, 2015, p. 48).

Há de ser destacado também que a orientação política dos(as) parlamentares ${ }^{10}$ que apresentaram os PLs e que solicitaram urgência para eles é bem variável, sendo essas etapas protagonizadas por representantes do MDB, PT, PSDB, PCdoB, PP, DEM, entre outros partidos. Em síntese: tanto congressistas que no espectro político encontram-se mais alinhados à esquerda quanto os mais à direita requereram a urgência regimental no processo de criminalização em estudo. O fato remonta à pesquisa legislativa realizada por Gazoto (2009) em sua tese doutoral, em que afirmou que todos os lados têm tendências punitivistas a depender do contexto.

No mesmo sentido, no que toca o tema da orientação partidária, conforme coloca Mariana Batista (2020), outra questão que merece ser levada em conta é que ainda que os partidos construam algum vínculo temático entre o(a) parlamentar e a espécie de PL que ele(a) apresentará, no fim das contas, pelo menos a proposição legislativa ainda é ato da disposição individual do(a) representante - um dos únicos do processo legislativo, por sinal (FIGUEIREDO; LIMONGI, 2001). Para chegar a essa conclusão, a autora percebeu, ao analisar a saliência temática dos Projetos na Câmara entre 1995 e 2014, que a distribuição dessas preferências entre os partidos,

\footnotetext{
${ }^{8}$ Na Câmara, o Projeto foi enumerado como PL 1749/2011; no Senado, PLC 79/2011. Resultou na Lei 12.550/2011. A Presidenta à época era Dilma Rousseff.

${ }^{9} \mathrm{O}$ outro foi o Projeto que originou a Lei 12.653/2012, de acordo com o colocado no item anterior.

${ }^{10}$ Isso na premissa despretensiosa de considerarmos a filiação partidária um indício legítimo, ainda que insuficiente, da orientação política dos(as) deputados(as) e senadores(as).
} 
na verdade, é um tanto quanto uniforme e pouco distinta entre eles, "[...] o que indica que o processo de proposição está mais sujeito a incentivos individuais do que à coordenação partidária" (BATISTA, 2020, p. 16). Portanto, mesmo que o partido deva construir sólidas bases e axiomas temáticos vinculados a sua orientação ideológica, na prática, em alguma medida, o entusiasmo mais ou menos punitivo dos(as) parlamentares, no que se refere ao assunto do presente trabalho, ainda pode estar refém de seus estímulos individuais e, por isso, não representar por completo o partido a qual se vincula.

Ao que se viu, não há também correlação natural do autor da proposta original ser quem irá requerer o regime de urgência — inclusive, na imensa maioria das vezes não foi isso o que ocorreu.

\subsection{Da ausência à carência de fundamentação para requerer o rito urgente e justificar a urgência da matéria}

Ao que se constatou da análise dos PLs que estiveram em regime urgente em alguma etapa de sua tramitação, tanto ao momento de votação do requerimento pelo Plenário da Câmara e do Senado quanto nas discussões deliberativas a respeito das iniciativas (não sobre o requerimento em específico, mas sim sobre os Projetos), a necessidade de urgência não foi satisfatoriamente justificada pelos(as) parlamentares.

No primeiro dos dois momentos, se observou que em nenhuma das tramitações a votação do requerimento pela urgência preocupou-se em fundamentar a decisão. Todas as vezes em que o pedido foi formalizado ele foi sumariamente aprovado. Os RIs das duas Casas não exigem dos(as) parlamentares a justificação do pedido de urgência, sendo suficiente apenas a breve menção ao artigo de subsunção. Por outro lado, preveem sim espaço para argumentação ao momento da votação do requerimento ${ }^{11}$. Acontece que essa possibilidade não foi explorada no trâmite de nenhum dos PLs examinados, tanto na Câmara dos Deputados como no Senado Federal.

Um possível fator que permita contextualizar esse cenário é o do regime de urgência ser deliberado previamente no colégio de líderes, deste modo, quando chega ao Plenário a tendência é a da votação ser apenas simbólica, principalmente, pela falta de espaço para a deliberação, e como consequência, pela formação de entraves à participação dos demais parlamentares (FIGUEIREDO; LIMONGI, 1995).

\footnotetext{
${ }^{11}$ Art. 343. No encaminhamento da votação de requerimento de urgência, poderão usar da palavra, pelo prazo de cinco minutos, um dos signatários e um representante de cada partido ou de bloco parlamentar e, quando se tratar de requerimento de autoria de comissão, o seu Presidente e o relator da matéria para a qual foi a urgência requerida (BRASIL, 1970, n.p.).

Art. 154. O requerimento de urgência somente poderá ser submetido à deliberação do Plenário se for apresentado por: [...] $\S 1^{\circ} \mathrm{O}$ requerimento de urgência não tem discussão, mas a sua votação pode ser encaminhada pelo Autor e por um Líder, Relator ou Deputado que lhe seja contrário, um e outro com o prazo improrrogável de cinco minutos. Nos casos dos incisos I e III, o orador favorável será o membro da Mesa ou de Comissão designado pelo respectivo presidente (BRASIL, 1989, n.p.).
} 
Já no segundo, na fase própria às discussões deliberativas nas Comissões e nos Plenários acerca das proposições, o que se viu, quando não ausente sequer a menção da necessidade da urgência, como se fosse inquestionável e natural, foi a delegação dessa necessidade a justificações externas e insuficientes, respondendo a agendas que clamam pelo aumento das demandas punitivas.

Nos debates e nos relatórios, foram identificadas ao menos três tendências marcantes desta última postura dos(as) legisladores, a de para defender a aprovação do Projeto imputar um suposto dever de urgência da matéria ${ }^{12}$ : (i) dispor o combate à impunidade como um estímulo premente; (ii) referenciar casos de grande repercussão midiática sobre a questão para fornecer ao problema a percepção indiscutível de que é recorrente, sólido e que clama por penalização; (iii) partir da premissa de que o caminho lógico para enfrentar o problema e esses casos é evocar a punição da conduta, como se fosse a única e esperada resposta que o Estado pode fornecer ao conflito.

Um exemplo a respeito da consignação de casos de grande repercussão para justificar a criminalização é o que se vê no trecho da Justificação do texto original do PL que originou a Lei 13.718/2018, assinada pela Senadora à época, Vanessa Grazziotin (PCdoB/AM):

Somente no mês de maio deste ano, no Estado do Piauí, quatro adolescentes foram vítimas de "estupro coletivo", sendo que uma delas morreu em razão das agressões sofridas. Já no Estado do Rio Grande do Norte, no mês de agosto, três casos de "estupro coletivo" foram amplamente noticiados pela mídia (BRASIL, 2015c, n.p.).

Ainda sobre essa tendência de mobilização de casos, se constatou também que alguns dos PLs foram apelidados com o nome de vítimas para fornecer sensibilização à demanda. É o caso da Lei 13.772/2018, de alcunha "Lei Rose Leonel". Ou ainda da Lei no 12.653/2012, chamada de "Lei Duvanier" em homenagem a Duvanier Paiva Ferreira, ex-Secretário de Recursos Humanos do Ministério do Planejamento do governo Dilma. A Lei criminaliza a específica conduta de condicionar atendimento médico-hospitalar emergencial a garantia após, em 19/01/2012 (menos de dois meses antes da apresentação do PL), Duvanier ter falecido em episódio correspondente a conduta que foi posteriormente tipificada. Com o exemplo, não se vem a desmerecer a gravidade do evento, apenas a se questionar a oportunidade e a conveniência em tratá-lo como criminoso.

Ainda como oportuno, um fato curioso da Lei $n^{\circ}$ 12.653/2012 é que ela tramitou em apenas 6 (seis) dias no Senado, desde o protocolo até a aprovação em Plenário. Na Câmara, foram apenas 1 (um) mês e 27 (vinte e sete) dias, a contar apenas da apresentação até a primeira aprovação em Plenário (BRASIL, 2012a).

\footnotetext{
12 Lembrando que, neste ponto, não se trata da menção à tramitação em regime de urgência. A postura a qual se menciona no parágrafo é aquela no âmbito discursivo de tratar a matéria (o tema do PL e sua criminalização), assim dito genericamente, como urgente e necessária para a sociedade.
} 
As três tendências identificadas acabam por representar de modo mais evidente a agenda daquilo que se entende por direito penal de emergência ${ }^{13}$. Conforme Ana Elisa Bechara (2008), o fenômeno se caracteriza pelo aceleramento da elaboração normativa, movida e a pedidos de uma opinião pública influenciada sobretudo pelas provocações midiáticas. Nesse sentido, a tendência ao maior rigor penal, ladeada na opinião de um senso comum que é abordado diariamente pela exposição exacerbada de selecionados delitos pelos meios de comunicação, a partir dos resultados desta pesquisa, se mantém inalterada desde a análise de Luís Gazoto (2010).

Ao que se nota quando o Congresso pauta problemas sociais, a intervenção penal sempre aparece como meio para a resolução, ainda que insuficiente, dessas demandas (SOUZA; FERRAZ, 2018). Abdicam, portanto, de soluções de outra natureza. Tal tendência se torna evidente, por exemplo, no procedimento legislativo que resultou na qualificadora do feminicídio, em especial, nos entraves enfrentados para aprovação do projeto. Inicialmente ele continha em sua redação inicial a referência a homicídios relacionados a questões de gênero - nomenclatura atualmente mais adequada e que dialoga com a construção de agendas feministas-, ao invés de referenciar expressamente a condição do sexo feminino, como consta no texto aprovado. A mudança de nomenclatura se deveu, dentre outras razões, à atuação comprometida do grupo parlamentar denominado popularmente como bancada da bíblia ${ }^{14}$ que possui como contumaz posicionamento barrar iniciativas que envolvam aquilo que entendem como ideologia de gênero, coibindo o desenvolvimento de qualquer política pública que de fato se centraria na resolução na raiz do problema (SOUZA; FERRAZ, 2018). Nesse sentido, fica consignada mais uma vez como não é rara a abdicação de se pensar estruturalmente os problemas públicos na agenda parlamentar, como acontece quando se delega à saída penal a única a ser investida.

Javier Quenta Fernández (2017) constrói o conceito de populismo penal como sendo um fenômeno originado nas demandas populares por punição. Nesse contexto, ao momento de construção da legislação criminal, as elites políticas percebem a potência do retorno em cumprir as expectativas (quase que sempre imediatas) desse(a) cidadão(ã) que opina e pensa a criminalidade, de tal forma que ante o crime a resposta é a de apenas criminalizar ainda mais a partir de justificativas que se apegam à gravidade e à indignação do fato, e não necessariamente em políticas públicas racionais. Ao cabo, o autor afirma:

É claro, então, que a função da pena no populismo punitivo não é outra senão satisfazer temporariamente as demandas sociais por maior segurança, por maior punição, para erradicar temporariamente os sentimentos de insegurança, vulnerabilidade e medo [...] (QUENTA FERNÁNDEZ, 2017, p. 140, tradução nossa).

A conceituação acima é importante para desenvolver a reflexão que se segue. Afinal,

\footnotetext{
${ }^{13}$ Sobre o tema ver: Tavares (1997); Bechara (2008); Batista (2010).

${ }^{14}$ Conhecida popularmente devido a ligação dos membros com as Igrejas de matriz cristã.
} 
ainda que se conceba, com base no presente estudo, que o imediatismo na apresentação de respostas legislativas seja problema que acomete o Congresso brasileiro e que a demanda por punição não tenha necessariamente partido político, o cenário aponta para a percepção de que a mobilização da urgência como efeito desse dito populismo penal é feita apenas na esfera discursiva sobre o Projeto em si, quando é oportunizado aos(às) parlamentares o palanque para comentar a proposição e acessar o seu eleitorado. Diferentemente, nos espaços de defesa do rito de urgência como procedimento legislativo inexistem, ao menos nos PLs analisados e nos documentos formais indexados aos trâmites, indícios para identificar o instituto como um grande aliado do direito penal de emergência ou como uma crucial ferramenta manipulada por esse tipo de agenda.

\section{Breves reflexões para o aprimoramento do instituto}

Diante do cenário trazido, torna-se indispensável que o pensamento acadêmico se volte a aprimorar o processo legislativo, em especial, no que toca ao trabalho, a elaborar critérios mais sólidos para o emprego da tramitação em urgência. Isto para que o regime urgente saia da situação que hoje se encontra de transigente aplicação e para que, ao cabo, se possa garantir mais transparência ao processo legiferante brasileiro.

Conforme se sabe, o Parlamento pode ser identificado como espaço de divergências, em que a escuta e o diálogo são utilizados como mecanismos de formação de consensos, seja por meio da convergência de ideias seja pelo próprio convencimento (BARCELLOS, 2017). Assim sendo, apesar das influências externas, o exercício legislativo é ato democrático, e, ainda que o instituto da urgência seja um mecanismo político, acredita-se, em respeito aos preceitos constitucionais da publicidade e do acesso à informação, que merece lapidações, principalmente devido a limitação que produz na participação dos(as) parlamentares - explorada no tópico 1 dentro do processo legiferante (BARCELLOS, 2017).

Como um primeiro passo, com status de mudança regimental, deveria tornar-se obrigatória a produção de justificativa mais robusta por parte dos legitimados dos arts. 338 e 154/155, respectivamente do RISF e RICD, para que determinado Projeto de Lei passe a tramitar em regime de urgência.

Para isso, como modestas sugestões e no movimento de conferir mais transparência ao caminho normativo sem que seja desrespeitada a autonomia legislativa dos representantes, elaboram-se as seguintes propostas: (1) reformular todas as hipóteses de requerimento, dos arts. 153 e 155 do RICD e art. 336 do RISF, que carreguem conjecturas abertas para solicitação como a defesa da sociedade democrática e das liberdades fundamentais, o perigo para a segurança nacional ou o relevante e inadiável interesse nacional; (2) modificar o art. 154, § $1^{\circ}$, do RICD (BRASIL, 1989) e o art. 343 do RISF (BRASIL, 1970) para tornar obrigatório o uso da palavra para a defesa do pedido de urgência pelo(a) parlamentar ou representante proponente no momento 
anterior à votação pelo Plenário; (3) adicionar também ao procedimento de aprovação da urgência via colégio de líderes a obrigatoriedade da justificativa pelos votantes.

Outrossim, em decorrência da importância do colégio de líderes para a tomada de decisão legislativa, torna-se necessário a extensão desta publicidade constitucional para as atas deste colegiado, tanto para garantir o acesso à informação dos(as) cidadãos(ãs) sobre as motivações desse mecanismo de negociação política, quanto para os(as) próprios(as) parlamentares que não detém posição de liderança partidária, terem subsídios para o questionamento da requisição, e assim, garantir a ampliação da participação no processo legislativo.

\section{Conclusão}

De antemão, salta aos olhos que a suposição feita a priori de que o emprego do regime de urgência poderia ser um mecanismo muito potente para demandas manipuladas por um direito penal de emergência restou vencida ao longo da pesquisa. O que surpreendeu, por sua vez, é que além dele não funcionar como essa ferramenta, a justificação e a utilização da tramitação urgente, mesmo em matéria criminal, pareceram ser tratadas com reduzida relevância na prática legiferante.

Chega-se a essa conclusão em função de, pelo menos, três razões. Primeiro, inexistem critérios formais robustos nos regimentos das Casas para a formulação do requerimento de urgência, bastando apenas os legitimados para isso o solicitarem de forma genérica. A lacuna evidencia que os(as) parlamentares não precisam esclarecer a opção pelo rito urgente e que, independentemente disso, o requerimento será aprovado. O pedido apenas é porque é.

Segundo, independentemente de ter havido ou não o assentimento para que o trâmite urgente prospere, não existe um padrão temporal de aprovação dos PLs analisados. A situação demonstra que subsistem dentro dos arranjos políticos do Congresso diversas outras razões, explícitas ou não, para além do rito urgente em si, que tornam um projeto elegível como mais ou menos prioritário.

Nesse ponto, a preocupação, contudo, não é a de simplesmente lamentar o pouco efeito do instituto. $\mathrm{O}$ que se pretende sustentar é que, mesmo não sendo o fator preponderante em ditar o ritmo da tramitação, ele ainda é capaz de dispensar diversas formalidades regimentais. No entanto, ainda que a escolha do regime seja importante e altere formalmente o rito legislativo, na prática, não se observa nenhum rigor para ser utilizado. Ao cabo, a preocupação primordial advém dele naturalmente encurtar o trâmite e, ao não ser acompanhado de argumentações aprofundadas sobre acabar sendo reduzido a uma maneira de limitar os debates legislativos.

Já a terceira razão deriva-se da constatação de que os espaços previstos regimentalmente como possíveis a produzir justificações pela urgência da tramitação e do Projeto encontram-se esvaziados ou prejudicados pelos(as) parlamentares. Tanto as votações do requerimento de urgência - para quando se trata do interesse próprio à tramitação - como os debates nas 
Comissões e nos Plenários - para quando se trata do interesse próprio à relevância daquela matéria criminal para a sociedade - carecem de argumentos robustos em prol da necessidade da urgência.

Apesar disso, quando não completamente ausente essa justificação pela urgência da tramitação ou da matéria, o que se tem são alegações e subterfúgios que se resumem a discursos moralizantes, advindos do populismo penal do qual o(a) legislador(a) não raras vezes adota enquanto padrão. Isto, pois, além de se ter em vista a menção de casos com repercussão midiática e o uso sistemático do discurso contra a impunidade como impulso na grande maioria das justificativas analisadas, os(as) parlamentares resumem a necessidade do Estado intervir a partir da criminalização como sendo a sua única política pública.

A busca por um processo legislativo mais racional, especialmente dentro da disciplina penal já tão sujeita a influências apaixonadas, merece se colocar contra esse movimento de tornar diminuto o regime de urgência. É necessário compreender que a melhora de seu emprego não pode ser lida como artifício supérfluo de complicação ou prolongamento da tramitação. Ele é, na verdade, importante na promoção da ausência de vícios dentro do procedimento legiferante motivo pelo qual se elencou sugestões de mudança no trabalho.

A situação merece ser aprimorada para, em especial, imputar mais transparência ao processo legislativo, com o intuito do Parlamento não apenas justificar o motivo de determinada matéria fazer jus a uma corrida mais veloz como também para esclarecer a razão das demais não o fazerem. Se o estabelecimento de critérios já é essencial em todo e qualquer procedimento, dentro da área criminal é especialmente vital já que é nela que o Estado opera a sua mais ofensiva agenda.

\section{Referências}

ALMEIDA, Acir. Processo legislativo: mudanças recentes e desafios. Boletim de Análise Político-Institucional (Ipea), Brasília, n. 7, p. 45-50, jul. 2015. Notas de Pesquisa. Disponível em: http://repositorio.ipea.gov.br/handle/11058/6788?locale=pt_BR. Acesso em: 15 ago. 2020.

ANÁLISE das justificativas para a produção de normas penais. Série Pensando o Direito. Brasília: Ministério da Justiça, v. 32, 2009. Disponível em: https://www.justica.gov.br/seusdireitos/elaboracao-legislativa/sispenas/anexos/32pensando_direito.pdf. Acesso em: 20 ago. 2020.

BARCELLOS, Ana Paula. Direitos fundamentais e direito à justificativa: devido procedimento na elaboração normativa. Belo Horizonte: Fórum, 2017.

BATISTA, Mariana. Quais políticas importam? Usando ênfases na agenda legislativa para mensurar saliência. Revista Brasileira de Ciências Sociais, v.35, n.104, 2020. Disponível em: https://www.scielo.br/scielo.php?pid=S010269092020000300508\&script=sci_abstract\&tlng=pt. Acesso em: 20 ago. 2020.

BATISTA, Nilo. A lei como pai. Passagens - Revista Internacional de História Política e Cultura Jurídica, v. 2, n. 3, p. 20-38, 2010. Disponível em: https://www.historia.uff.br/revistapassagens/artigos/v2n3a22010.pdf. Acesso em: 12 ago. 2020. BECHARA, Ana Elisa Liberatore Silva. Discursos de emergência e política criminal: o futuro 
do direito penal brasileiro. Revista da Faculdade de Direito, Universidade de São Paulo, v. 103, p. 411-436, 2008. Disponível em: https://www.revistas.usp.br/rfdusp/article/view/67812. Acesso em 14 ago. 2020.

BRASIL. Câmara dos Deputados. Projeto de Lei da Câmara no 2793/2011, de 29 de maio de 2019. Dispõe sobre a tipificação criminal de delitos informáticos; altera o Decreto-Lei ${ }^{\circ} 2.848$, de 7 de dezembro de 1940 - Código Penal; e dá outras providências. Brasília: Câmara dos Deputados, 2019. Disponível em:

www.camara.leg.br/proposicoesWeb/fichadetramitacao?idProposicao=529011. Acesso em: 12 ago. 2020.

BRASIL. Câmara dos Deputados. Projeto de Lei no 1749/2011, de 05 de julho de 2011. Autoriza o Poder Executivo a criar a empresa pública denominada Empresa Brasileira de Serviços Hospitalares S.A. - EBSERH e dá outras providências. Brasília: Câmara dos Deputados, 2011. Disponível em: https://www.camara.leg.br/proposicoesWeb/fichadetramitacao?idProposicao=511029. Acesso em: 12 ago. 2020.

BRASIL. Câmara dos Deputados. Projeto de Lei no 3331/2012, de 06 de março de 2012. Acresce o art. 135-A ao Decreto-Lei no 2.848, de 7 de dezembro de 1940 - Código Penal, para tipificar o crime de condicionar atendimento médico-hospitalar emergencial a qualquer garantia e dá outras providências. Brasília: Câmara dos Deputados, 2012. Disponível em: https://www.camara.leg.br/proposicoesWeb/fichadetramitacao?idProposicao=535948. Acesso em: 12 ago. 2020.

BRASIL. Câmara dos Deputados. Projeto de Lei no 370/2007, de 08 de março de 2007. Dispõe sobre o crime de extermínio de seres humanos, e dá outras providências. Brasília: Câmara dos Deputados, 2007. Disponível em: https://www.camara.leg.br/proposicoesWeb/fichadetramitacao?idProposicao=344218. Acesso em: 12 ago. 2020

BRASIL. Câmara dos Deputados. Projeto de Lei no 643/2011, de 02 de março de 2011. Dá nova redação ao art. 334 do Código Penal e acrescenta o art. 334-A, também no Decreto-Lei n ${ }^{\circ}$ 2.848, de 7 de dezembro de 1940 - Código Penal. Brasília: Câmara dos Deputados, 2011a. Disponível em: https://www.camara.leg.br/proposicoesWeb/fichadetramitacao?idProposicao=494004. Acesso em: 12 ago. 2020.

BRASIL. Câmara dos Deputados. Projeto de Lei no 6920/2010, de 09 de março de 2010. Dispõe sobre estelionato cometido contra idosos. Brasília: Câmara dos Deputados, 2010. Disponível em: https://www.camara.leg.br/proposicoesWeb/fichadetramitacao?idProposicao=468486. Acesso em: 12 ago. 2020.

BRASIL. Câmara dos Deputados. Projeto de Lei no 6999/2013, de 18 de dezembro de 2013. Dispõe sobre o crime de abigeato e sobre o comércio de carne e outros alimentos sem procedência legal, e dá outras providências. Brasília: Câmara dos Deputados, 2013. Disponível em: https://www.camara.leg.br/proposicoesWeb/fichadetramitacao idProposicao=604844.

Acesso em: 12 ago. 2020.

BRASIL. Câmara dos Deputados. Projeto de Lei no 7370/2014, de 04 de abril de 2014. Dispõe sobre prevenção e repressão ao tráfico interno e internacional de pessoas e sobre medidas de atenção às vítimas; altera o Decreto-Lei n ${ }^{\circ}$ 2.848, de 7 de dezembro de 1940 (Código Penal), e as Leis n ${ }^{\circ}$ s 6.815, de 19 de agosto de 1980, e 7.998, de 11 de janeiro de 1990; e revoga dispositivos do Decreto-Lei n 2.848 , de 7 de dezembro de 1940 (Código Penal). Brasília: Câmara dos Deputados, 2014. Disponível em: https://www.camara.leg.br/proposicoesWeb/fichadetramitacao?idProposicao=611445. Acesso em: 12 ago. 2020.

BRASIL. Câmara dos Deputados. Projeto de Lei no 8305/2014, de 17 de dezembro de 2014a. 
Altera o art. 121 do Decreto-Lei no 2.848 , de 7 de dezembro de 1940 (Código Penal), para prever o feminicídio como circunstância qualificadora do crime de homicídio, e o art. $1^{\circ}$ da Lei $\mathrm{n}^{\circ}$ 8.072, de 25 de julho de 1990, para incluir o feminicídio no rol dos crimes hediondos. Brasília: Câmara dos Deputados, 2014a. Disponível em:

https://www.camara.leg.br/proposicoesWeb/fichadetramitacao?idProposicao=858860. Acesso em: 12 ago. 2020.

BRASIL. Câmara dos Deputados. Projeto de Lei no 8833/2017, de 10 de outubro de 2017. Acrescenta o art. 244-C à Lei no 8.069, de 13 de julho de 1990 (Estatuto da Criança e do Adolescente), para tipificar o crime de induzimento, instigação ou auxílio à automutilação de criança ou adolescente. Brasília: Câmara dos Deputados, 2017. Disponível em:

https://www.camara.leg.br/proposicoesWeb/fichadetramitacao?idProposicao=2155635. Acesso em: 12 ago. 2020.

BRASIL. Câmara Dos Deputados. Projeto de Lei $\mathbf{n}^{\mathbf{0}}$ PL 2916/2015, de 04 de agosto de 2015. Acrescenta os arts. 218-C e 225-A ao Decreto-Lei no 2.848, de 7 de dezembro de 1940 (Código Penal), para tipificar o crime de divulgação de cena de estupro e prever causa de aumento de pena para o crime de estupro cometido por duas ou mais pessoas. Brasília: Câmara dos Deputados, 2015. Disponível em: https://www.camara.leg.br/proposicoesWeb/fichadetramitacao?idProposicao=1594910. Acessado em: 12 ago. 2020.

BRASIL. Câmara Dos Deputados. Projeto de Lei no PL 5452/2016, de 01 de junho de 2016. Acrescenta os arts. 218-C e 225-A ao Decreto-Lei no 2.848, de 7 de dezembro de 1940. Brasília: Câmara dos Deputados, 2016. Disponível em:

https://www.camara.leg.br/proposicoesWeb/fichadetramitacao?idProposicao=2086414. Acessado em: 12 ago. 2020.

BRASIL. Câmara Dos Deputados. Projeto de Lei no PL 5555/2013, de 09 de maio de 2013. Altera a Lei no 11.340, de 7 de agosto de 2006 - Lei Maria da Penha. Brasília: Câmara dos Deputados, 2013a. Disponível em:

https://www.camara.leg.br/proposicoesWeb/fichadetramitacao?idProposicao=576366. Acessado em: 12 ago. 2020.

BRASIL. Câmara dos Deputados. Resolução da Câmara dos Deputados no 17, de 1989: Regimento Interno da Câmara dos Deputados, atualizado até a Resolução no 12/2019. Brasília: Câmara dos Deputados, 1989. Disponível em: https://www2.camara.leg.br/atividadelegislativa/legislacao/regimento-interno-da-camara-dos-deputados. Acesso em 14 ago. 2020.

BRASIL. Decreto-Lei no 2.848, de 7 de dezembro de 1940. Código Penal. Rio de Janeiro: Presidência da República, 1940. Disponível em: http://www.planalto.gov.br/ccivil_03/decretolei/del2848compilado.htm. Acesso em: 10 de ago. 2020.

BRASIL. Senado Federal. Projeto de Lei da Câmara $\mathbf{n}^{\mathbf{0}}$ 128, de 09 de setembro de 2015. Altera o Decreto-Lei $n^{\circ} 2.848$, de 7 de dezembro de 1940 - Código Penal, para tipificar, de forma mais gravosa, os crimes de furto e receptação de semoventes domesticáveis de produção, ainda que abatidos, e a Lei $\mathrm{n}^{\mathrm{o}}$ 8.137, de 27 de dezembro de 1990, que define crimes contra as relações de consumo, para punir o comércio de carne ou outros alimentos sem procedência lícita. Brasília: Senado Federal, 2015a. Disponível em:

https://www25.senado.leg.br/web/atividade/materias/-/materia/123107. Acesso em: 12 ago. 2020.

BRASIL. Senado Federal. Projeto de Lei da Câmara no 137, de 04 de setembro de 2008. Dispõe sobre o crime de extermínio de seres humanos, altera o Decreto-Lei $\mathrm{n}^{\circ} 2.848$, de 7 de dezembro de 1940 - Código Penal, e dá outras providências. Brasília: Senado Federal, 2008. Disponível em: https://www25.senado.leg.br/web/atividade/materias/-/materia/87259. Acesso em: 12 ago. 2020.

BRASIL. Senado Federal. Projeto de Lei da Câmara no 18, de 07 de março de 2017. Inclui a comunicação no rol de direitos assegurados à mulher pela Lei Maria da Penha, bem como 
reconhece que a violação da sua intimidade consiste em uma das formas de violência doméstica e familiar; tipifica a exposição pública da intimidade sexual; e altera a Lei n ${ }^{\circ} 11.340$ de 7 de agosto de 2006 (Lei Maria da Penha), e o Decreto-Lei n ${ }^{\circ}$ 2.848, de 7 de dezembro de 1940 (Código Penal). Brasília: Senado Federal, 2017a. Disponível em:

https://www25.senado.leg.br/web/atividade/materias/-/materia/128223. Acesso em: 12 ago. 2020.

BRASIL. Senado Federal. Projeto de Lei da Câmara no 23, de 01 de abril de 2015. Altera o Decreto-Lei $n^{\circ}$ 2.848, de 7 de dezembro de 1940 - Código Penal, para estabelecer causa de aumento de pena para o caso de estelionato cometido contra idoso. Brasília: Senado Federal, 2015b. Disponível em: https://www25.senado.leg.br/web/atividade/materias//materia/120492\#: :text=Vota\%C3\%A7\%C3\%A3o\%20nominal\%20do\%20PLC\%2023\%2F201 $5 \% 20$ que $\% 20$ altera $\% 20 \mathrm{o} \% 20$ Decreto,de $\% 20$ estelionato $\% 20$ cometido $\% 20$ contra $\% 20$ idoso. Acesso em: 12 ago. 2020.

BRASIL. Senado Federal. Projeto de Lei da Câmara no 34, de 04 de maio de 2012. Acresce o art. 135-A ao Decreto-Lei n 2.848 , de 7 de dezembro de 1940 - Código Penal, para tipificar o crime de condicionar atendimento médico-hospitalar emergencial a qualquer garantia e dá outras providências. Brasília: Senado Federal, 2012a. Disponível em: https://www25.senado.leg.br/web/atividade/materias/-/materia/105396. Acesso em: 12 ago. 2020.

BRASIL. Senado Federal. Projeto de Lei da Câmara no 35, de 17 de maio de 2012. Dispõe sobre a tipificação criminal de delitos informáticos; altera o Decreto-Lei no 2.848 , de 7 de dezembro de 1940 - Código Penal; e dá outras providências. Brasília: Senado Federal, 2012b. Disponível em: https://www25.senado.leg.br/web/atividade/materias/-/materia/105612. Acesso em: 12 ago. 2020.

BRASIL. Senado Federal. Projeto de Lei da Câmara no 62, de 21 de junho de 2012. Dá nova redação ao art. 334 do Decreto-Lei no 2.848, de 7 de dezembro de 1940 - Código Penal e acrescenta-lhe o art. 334-A. Brasília: Senado Federal, 2012c. Disponível em: https://www25.senado.leg.br/web/atividade/materias/-/materia/106132. Acesso em: 12 ago. 2020.

BRASIL. Senado Federal. Projeto de Lei da Câmara no 79, de 21 de setembro de 2011. Autoriza o Poder Executivo a criar a empresa pública denominada Empresa Brasileira de Serviços Hospitalares - EBSERH; acrescenta dispositivos ao Decreto-Lei no 2.848, de 7 de dezembro de 1940 - Código Penal; e dá outras providências. Brasília: Senado Federal, 2011b. Disponível em: https://www25.senado.leg.br/web/atividade/materias/-/materia/102439. Acesso em: 12 ago. 2020.

BRASIL. Senado Federal. Projeto de Lei do Senado no 288, de 19 de novembro de 2018. Institui a Lei de Migração e regula entrada e estada de estrangeiros no Brasil. Brasília: Senado Federal, 2018. Disponível em: https://www25.senado.leg.br/web/atividade/materias//materia/113700. Acesso em: 12 ago. 2020.

BRASIL. Senado Federal. Projeto de Lei do Senado no 292, de 15 de julho de 2013. Altera o Código Penal, para inserir o feminicídio como circunstância qualificadora do crime de homicídio. Brasília: Senado Federal, 2013b. Disponível em: https://www25.senado.leg.br/web/atividade/materias/-/materia/113728. Acesso em: 12 ago. 2020.

BRASIL. Senado Federal. Projeto de Lei do Senado no 479, de 20 de dezembro de 2012. Dispõe sobre prevenção e punição ao tráfico interno e internacional de pessoas, bem como sobre medidas de proteção às vítimas. Brasília: Senado Federal, 2012d. Disponível em: https://www25.senado.leg.br/web/atividade/materias/-/materia/110044. Acesso em: 12 ago. 2020.

BRASIL. Senado Federal. Projeto de Lei do Senado no 618, de 16 de setembro de 2015. Acrescenta o art. 225-A ao Decreto-Lei n ${ }^{\circ}$ 2.848, de 7 de dezembro de 1940 - Código Penal, 
para prever causa de aumento de pena para o crime de estupro cometido por duas ou mais pessoas. Brasília: Senado Federal, 2015c. Disponível em:

https://www25.senado.leg.br/web/atividade/materias/-/materia/123183. Acesso em: 12 ago. 2020.

BRASIL. Senado Federal. Projeto de Lei do Senado ${ }^{\mathbf{0}}$ 664, de 01 de outubro de 2015. Inclui o art. 244-C na Lei no . 8.069, de 13 de julho de 1990 - Estatuto da Criança e do Adolescente, para tipificar o crime de induzimento, instigação ou auxílio à automutilação de criança ou adolescente. Brasília: Senado Federal, 2015d. Disponível em:

https://www25.senado.leg.br/web/atividade/materias/-/materia/123447. Acesso em: 12 ago. 2020.

BRASIL. Senado Federal. Resolução do Senado Federal n $^{0} 93$ de 27 de novembro de 1970: Regimento Interno do Senado Federal, atualizado até 24/09/2019. Brasília: Senado Federal, 1970. Disponível em: https://www25.senado.leg.br/web/atividade/regimento-interno. Acesso em: 14 ago. 2020.

DÍEZ RIPOLLÈS, José Luis. A racionalidade das leis penais: Teoria e Prática. 2. ed. Florianópolis: Revista dos Tribunais, 2016.

FIGUEIREDO, Argelina Cheibub; LIMONGI, Fernando de Magalhães Papaterra. Executivo e Legislativo na nova ordem constitucional. Rio de Janeiro: Editora FGV, 1999.

FIGUEIREDO, Argelina Cheibub; LIMONGI, Fernando. Mudança constitucional, desempenho do Legislativo e consolidação institucional. Revista Brasileira de Ciências Sociais, v. 10, $\mathrm{n}$. 29, p. 175-200, 1995. Disponível em:

https://www.academia.edu/download/34221297/FIGUEREDO_E_LIMONGI_-_artigo__Mudanca_constitucional_desempenho_do_Legislativo_e_consolidacao_institucional.pdf. Acesso em 13 ago. 2020.

GAZOTO, Luís Wanderley. Justificativas do congresso nacional brasileiro ao rigor penal legislativo: o estabelecimento do populismo penal no brasil contemporâneo. 2010. 377 f. Tese (Doutorado em Sociologia) - Departamento de Sociologia, Universidade de Brasília, Brasília, 2010. Disponível em:

https://repositorio.unb.br/bitstream/10482/6661/3/2010_LuisWanderleyGazoto.pdf. Acesso em: 12 ago. 2020.

MARINA, Feferbaum; RABELO, Queiroz Rafael Mafei. Metodologia da pesquisa em direitotécnicas e abordagens para elaboração de monografias, dissertações e teses: Técnicas e abordagens para elaboração de monografias, dissertações e teses. 2. ed. São Paulo: Saraiva. 2019.

MENDES, Simone Crema. A urgência constitucional e o seu reflexo no processo legislativo. 2002. 91 f. Monografia (Especialização) - Curso de Formação de Secretário de Comissão, Centro de Formação, Treinamento e Aperfeiçoamento (Cefor), Universidade de Brasília (Unb) e Câmara dos Deputados, Brasília, 2002. Disponível em:

https://bd.camara.leg.br/bd/handle/bdcamara/2492. Acesso em: 12 ago. 2020.

QUENTA FERNÁNDEZ, Javier. El Populismo del Derecho penal: La necesidad de racionalizar las leyes punitivas populares. Revista Jurídica Derecho, v. 5, n. 6, p. 133-154, 2017.

Disponível em: http://www.scielo.org.bo/scielo.php?script=sci_arttext\&pid=S241328102017000100009\&lng=es\&nrm=iso. Acesso em 21 ago. 2020.

SOUZA, Luciano Anderson; FERRAZ, Júlia Lambert Gomes. Desvios na construção de um Direito Penal de gênero: um problema chamado Poder Legislativo. Revista brasileira de ciências criminais, n. 147, p. 459-477, 2018.

TAVARES, Juarez. A crescente legislação penal e os discursos de emergência. Discursos sediciosos, n. 4, p. 48, 1997.

Artigo submetido em: 2021-03-18; reapresentado em: 2021-04-10; aceito em: 2021-04-23 